\title{
HARVARD
}

JOHN M. OLIN CENTER FOR LAW, ECONOMICS, AND BUSINESS

\section{EX ANTE COSTS OF VIOLATING ABSOLUTE PRIORITY IN BANKRUPTCY}

Lucian Arye Bebchuk

Harvard Law School

Discussion Paper No. 328

$06 / 2001$

As published in:

Journal of Finance, Vol.57, 445-460 (2002)

This paper can be downloaded without charge from:

The Social Science Research network Electronic Paper collection:

http://papers.ssrn.com/abstract_id=277428 


\title{
Ex Ante Costs of Violating Absolute Priority in Bankruptcy
}

\author{
Lucian Arye Bebchuk ${ }^{*}$
}

\begin{abstract}
A basic question for the design of bankruptcy law concerns whether value should be divided in accordance with absolute priority. Research done in the past decade has suggested that deviations from absolute priority have beneficial ex ante effects. In contrast, this paper shows that ex post deviations from absolute priority also have negative effects on ex ante decisions taken by shareholders. Such deviations aggravate the moral hazard problem with respect to project choice -- increasing the equityholders' incentive to favor risky projects -- as well as with respect to borrowing and dividend decisions.
\end{abstract}

JEL classification: G33, K20, K22

Key words: Bankruptcy, Chapter 11, corporate reorganizations, workouts, absolute priority, moral hazard, asset dilution, claim dilution,

* William J. Friedman and Alicia Townsend Friedman Professor of Law, Economics, and Finance, Harvard Law School; Research Associate, National Bureau of Economic Research. An earlier version of this paper, entitled, "The Effects of Chapter 11 and Debt Renegotiation on Ex Ante Corporate Decisions," was circulated as Discussion Paper No. 104, Program in Law and Economics, Harvard Law School. For their comments, I am grateful to Howard Chang, Milton Harris, Oliver Hart, Christine Jolls, Marcel Kahan, Louis Kaplow, Reinier Kraakman, Steve Shavell, Lars Stole, Rene Stulz, Michelle White, three anonymous referees, and participants in workshops at Chicago, Harvard, Michigan, and Tel Aviv for their helpful comments; and to the National Science Foundation and the Harvard John M. Olin Center for Law, Economics, and Business for their financial support. 
The bankruptcy rules of the United States often enable the equityholders of companies in financial distress to extract deviations from absolute priority (AP) - that is, obtain some value even when the debtholders are not paid in full. One important way in which the equityholders can do so is by putting (or threatening to put) the company in Chapter 11 (Ch. 11) of the Bankruptcy Code. Once Ch. 11 is commenced, there is an "automatic stay" that prevents debtholders from getting any value until a reorganization plan is adopted. The equityholders can use their power to prevent or delay the adoption of a reorganization plan in order to extract deviations from AP. ${ }^{1}$ Indeed, there is a large body of empirical work documenting that significant deviations from AP are common in Ch. 11 reorganizations. ${ }^{2}$ Furthermore, having the threat to put the company into Ch. 11 also strengthens the ability of equityholders to extract deviations from AP in "workouts" negotiated outside a formal bankruptcy. ${ }^{3}$ The deviations from AP under Ch. 11, it should be stressed, arise from the structure of its rules. The rules of Chapter 7 of the Bankruptcy Code, and the rules governing receiverships in the U.K., generally produce a division of value that is consistent with $\mathrm{AP}^{4}$

While the distributive consequences of alternative bankruptcy rules are by themselves irrelevant for efficiency, the substantial interest in them by financial economists reflects the recognition that such consequences might have significant ex ante efficiency effects. Economists have devoted much attention to analyzing optimal bankruptcy procedures and bankruptcy reform. One important goal for bankruptcy rules is attaining an optimal division of

\footnotetext{
${ }^{1}$ See Bebchuk and Chang (1992) for a bargaining model that identifies the sources of the equityholders' power to extract value from debtholders.

${ }^{2}$ See, e.g., Franks and Torous (1989), Eberhart, Moore, and Roenfeldt (1990), Weiss (1990), Franks and Torous (1994), Betker (1995), and, most recently, Carapeto (2000).

${ }^{3}$ For a theoretical analysis of how the availability of Ch. 11 shapes the bargaining in workouts outside bankruptcy, see Brown (1989), White (1989), and Berkovitch and Israel (1998). For empirical studies of such workouts, and of the concessions made in them by debtholders, see Gilson, John, and Lang (1990), and Franks and Torous (1994).

${ }^{4}$ For a comparison of U.S. and U.K. law, see Franks, Nybourg, and Torous (1996).
} 
bankruptcy value (see, e.g., Hart (1995) and Bebchuk (1998)). ${ }^{5}$ The ex post division that is optimal is the one that would have the best overall effect on ex ante incentives and behavior.

Much of the research on bankruptcy procedures and reform (though, as noted below, not all of it) has assumed that AP is the optimal division and has focused on procedures that could secure AP. One approach that could attain AP and that has received substantial attention is that of conducting an auction (see Baird (1986), Jensen (1991), Bhattacharyya and Singh (1999), and Rhodes-Kropf and Viswanathan (2000)). Another approach that could attain AP is based on the use of options (see Bebchuk (1988, 2000), Aghion, Hart, and Moore (1992)).

As noted, to identify the ex post division of value that is optimal, it is necessary to analyze fully the ex ante effects that this division has. Some substantial research has already been done, and it has generally suggested that the ex ante effects of deviations from AP are actually beneficial. In particular, this line of research has shown that deviations from AP encourage desirable ex ante investments in firm-specific human capital (Bebchuk and Picker (1993), Berkovitch, Israel, and Zender (1997, 1998)); that they facilitate the transfer of information to creditors and improve the timing of decisions to file for bankruptcy, to liquidate, or to recapitalize (Baird (1991)), Heinkel and Zechner (1993), Povel (1996), and Berkovitch and Israel $(1998,1999))$; that they discourage excessive risk-taking by financially distressed firms (Eberhart and Senbet (1993) and Gertner and Scharfstein (1991)); and that they help address an under-investment problem in financially distressed firms with debt overhang (Berkovitch and Israel (1998), Gertner and Scharfstein (1991)), and White (1989)).

The above line of research suggests that the substantial work seeking to design procedures that would attain AP is at least unwarranted if not misguided. It also suggests that the rules of Ch. 7 and the rules of U.K. receiverships should be reconsidered. This line of

\footnotetext{
${ }^{5}$ The other widely recognized goal of bankruptcy procedures is maximizing the ex post value of assets. This goal includes the objective of reducing the costs of the bankruptcy process (the evidence on the size of these costs is mixed, see, e.g., Cutler and Summers (1988), Lang and Stulz (1992), Warner (1977)) and the objective of ensuring an ex post efficient allocation of the assets.
} 
research has already had an impact on the ongoing work on bankruptcy procedures and reforms. It has led to proposals to adopt procedures aimed at producing certain deviations from AP (see, e.g., Berkovitch, Israel, and Zender (1998)). Indeed, this research has even forced researchers who earlier put forth mechanisms aimed at attaining AP to examine how their mechanisms could be adjusted to produce distributions deviating from AP (Bebchuk (1999)).

This paper analyzes the negative ex ante effects that ex post deviations from AP have. Such deviations have an adverse effect on ex ante management decisions made prior to the onset of financial distress. In the presence of debt, equityholders might make "inefficient" management decisions concerning investment, distribution of dividends, and financing (see Jensen and Meckling (1976)). As will be shown, the presence of AP violations aggravates this moral hazard problem and increases its efficiency costs.

In particular, deviations from AP increase the bias of equityholders' decisions in favor of riskier investments (Jensen and Meckling (1976), Green (1984)). Equityholders (and managers seeking to maximize the value of equity) might favor a risky project over a safer one even if the risky project offers a somewhat lower expected return, because the returns from favorable outcomes of the risky project would be captured by the equityholders, whereas the losses from its unfavorable outcomes would be partly borne by the debtholders. As this paper shows, ex post deviations from AP produced by Ch. 11 or otherwise strengthen this distortion in favor of risky projects.

The intuition underlying this result is that AP violations operate to increase what the equityholders would receive in bad times and thus the fraction of the downward risk that would be borne by the debtholders. ${ }^{6}$ This increase aggravates the distortion in favor of risky projects, because it is the prospect of shifting downward risk to debtholders that creates this distortion. Moreover, the introduction of AP violations increases the nominal interest rate (to compensate the debtholders for getting less in bad times), and this increase in the nominal rate worsens further the distortion in 
favor of risky projects, because such an increase lowers the attractiveness of safe projects more than it lowers the attractiveness of risky projects. (With a risky project, the likelihood that the increased nominal rate would actually be paid is smaller than with a safe project.)

While the model focuses on how AP violations aggravate the extent to which choices among projects are distorted by moral hazard, the model's logic also applies to other management decisions that are subject to moral hazard - such as those concerning the distribution of dividends and the taking of extra debt. Deviations from AP strengthen the moral hazard problem also with respect to such decisions.

Finally, it is worth nothing that, by assuming that there is only one class of debtholders, the analysis of this paper abstracts from questions concerning the division of value between two or more classes of debtholders. Such classes of debt exist in many cases, often due to the presence of secured debt. Because no class of debtholders is ex ante in control of the company, the ex ante effects of the division of the total value given to debtholders among different classes of debt are different from the ex ante effects of the division of value between equity and debt. Bebchuk and Fried (1996) analyze the ex ante effects of the division of value between secured and unsecured debt, and Bebchuk and Fried (2001) put forward a market-based mechanism for implementing whatever division of the value between secured and unsecured debt is desired.

The analysis is organized as follows. Section I presents the framework of analysis. Section II analyzes ex ante behavior and share value in a regime without deviations from AP. Section III analyzes behavior and share value in the presence of such deviations. Section IV discusses the generality of the model's results. Finally, Section V concludes.

\section{The Model}

The sequence of events in the model is as follows. At time $t=0$, a company borrows an

${ }^{6}$ This intuition was first noted in Bebchuk (1991), an early version of the model of this paper, and Adler 
amount $\mathrm{D}>0$. At time $\mathrm{t}=1$, the equityholders will make a choice between two projects (or business strategies) in which the firm's assets (including the borrowed funds) can be deployed: one is "safe," the other is "risky." Finally, at time $t=2$, the firm's final output $\mathrm{W}$ is realized, and this output is divided between the equityholders and the debtholders.

\section{A. The Initial Debt Contract}

It is assumed for simplicity that all participants are risk-neutral. Let i denote the interest rate set by the participants at $\mathrm{t}=0$ for the period between the raising and payment of debt; that is, at $\mathrm{t}=2$ the company will owe its debtholders the amount $\mathrm{D}(1+i)$. Let $\mathrm{i}_{0}$ denote the corresponding riskless interest rate. Given risk neutrality, the parties must choose $i \geq i_{0}$ such that the expected return to the debtholders is at least $i_{0}$. We assume that potential debtholders compete to offer the interest rate $\mathrm{i}$ most favorable to the equityholders, subject to the debtholders' "individual rationality" constraint that the expected payment to the debtholders is at least $\mathrm{D}\left(1+\mathrm{i}_{0}\right)$.

\section{B. The Management Decision}

At $t=1$, the management decision of project choice is made. We assume that this management decision is made by the equityholders - or, equivalently, by managers seeking to serve the interests of the equityholders (at least as far as the considered management decision is concerned). We also assume that the equityholders' choice of project is not verifiable, so that it cannot be specified in the initial debt contract.

If the equityholders choose the "safe" project, then the final output W will be S, where S $>\mathrm{D}\left(1+\mathrm{i}_{0}\right)$. If they choose the risky project instead, then the final output $\mathrm{W}$ will be $\theta \mathrm{R}$, where $\mathrm{R}$ is the expected return, which is positive, and $\theta$ is a random variable with expected value equal 
to 1 . Let $\theta$ be distributed continuously with positive density throughout the interval $(0, \theta)$, where $\underline{\theta}>1$. At $t=1$, the equityholders observe $R$, but the value $\theta$ is realized at $t=2$.

At $\mathrm{t}=0$, all the participants know that at $\mathrm{t}=1$, the equityholders will choose between a safe project and a risky project. Not all the details of this choice, however, are known in advance. It is assumed that given the information available at $\mathrm{t}=0$, the parties know $\mathrm{S}$ but only the distribution of R. The risky project may offer a higher or lower expected return than the safe project. Specifically, let R be distributed continuously with positive density throughout the interval $(\mathrm{O}, \mathrm{R})$, where $\mathrm{R}>\mathrm{S}$. The moral hazard problem is that at $\mathrm{t}=1$ the equityholders may choose the risky project even if $\mathrm{R}<\mathrm{S}$.

\section{The Final Period}

At $t=2$, the final output $\mathrm{W}$ is realized and then divided between the equityholders and the debtholders. This division depends upon whether the option of filing for Ch. 11 is available. As explained earlier, the availability of Ch. 11 substantially increases the equityholders' power to extract deviations from AP. We assume that such deviations are possible only with Ch. 11 .

Thus, under the regime in which Ch. 11 is not available, the equityholders will not be able to extract concessions from the debtholders. If the firm is insolvent, $\mathrm{W}<\mathrm{D}(1+\mathrm{i})$, then its assets will be sold as a going concern through a Ch. 7 liquidation, and the proceeds will be applied first to cover the firm's debt. Thus, under this regime, the equityholders will receive $\max [\mathrm{W}-\mathrm{D}(1+\mathrm{i}), 0]$, and the debtholders will receive $\min [\mathrm{D}(1+\mathrm{i}), \mathrm{W}]$.

In contrast, under the Ch. 11 regime, the equityholders will be able to obtain some value regardless of how small $\mathrm{W}$ turns out to be. Specifically, if $\mathrm{W}<\mathrm{D}(1+\mathrm{i})$, the shareholders, by 
filing for Ch. 11 or threatening to do so, will be able to obtain $\alpha \mathrm{W}$ (where $\alpha>0$ ). ${ }^{7}$ Moreover, the equityholders, by using or threatening to use Ch. 11, will be able to obtain more than their contractual right if the firm is sufficiently close to "insolvency" - that is, if W exceeds $\mathrm{D}(1+\mathrm{i})$ by an amount that is sufficiently small. ${ }^{8}$ For simplicity, it will be assumed that the equityholders will always be able to get at least $\alpha \mathrm{W}$ even if their "contractual right" of $\mathrm{W}$ $\mathrm{D}(1+\mathrm{i})$ is less than that. That is, if $0<\mathrm{W}-\mathrm{D}(1+\mathrm{i})<\alpha \mathrm{W}$, the equityholders will get $\alpha \mathrm{W}$ while the debtholders will not get full payment but only $(1-\alpha) \mathrm{W}<\mathrm{D}(1+\mathrm{i})$. Thus, under the Ch. 11 regime, the equityholders will receive $\max [\mathrm{W}-\mathrm{D}(1+\mathrm{i}), \alpha \mathrm{W}]$, and the debtholders will receive $\min [\mathrm{D}(1+\mathrm{i}),(1-\alpha) \mathrm{W}]$. The assumption that the payoff to the equity in the event of insolvency will be a fixed fraction $\alpha$ of the value is made only for simplicity of notation; the results of the paper hold as long as the equityholders are able to get some value in the event that $\mathrm{W}<\mathrm{D}(1+\mathrm{i})$.

\section{The Initial Equity Value}

Let $\mathrm{V}_{0}$ be the ex ante value of the equity, that is, the expected value of the equity at $\mathrm{t}=$ 0. The question to be addressed is whether $\mathrm{V}_{0}$ is higher with or without Ch. 11. The debtholders in this model cannot be "cheated" by Ch. 11 - they will always capture an expected return $\mathrm{i}_{0}$. Therefore, the question of which regime implies a higher $\mathrm{V}_{0}$ is equivalent to the question of which regime leads to more efficient management decisions.

Let $\mathrm{V}_{0}{ }^{*}$ denote the first-best value for $\mathrm{V}_{0}$. Then:

\footnotetext{
${ }^{7}$ Bebchuk and Chang (1992) model the bargaining process in Ch. 11 and analyze how the fraction of value that the equityholders can obtain depends on the characteristics of the firm in Ch. 11 and on the legal rules of Ch. 11. For our purposes, which are to understand how the ability to extract some value affects certain $e x$ ante decisions, it seems appropriate to use a simple, reduced-form representation of the outcome in the $\mathrm{Ch}$. 11 bargaining.

It should be noted that an assumption made later on is that $\alpha<[\mathrm{S}-\mathrm{D}(1+\mathrm{i})]) / \mathrm{S}$. This assumption will be made to simplify the analysis by ensuring that only the risky project (but not the safe project) may lead to bankruptcy.
} 


$$
\mathrm{V}_{0}{ }^{*}=[\operatorname{Pr}(\mathrm{R} \leq \mathrm{S})] \mathrm{S}+[\operatorname{Pr}(\mathrm{R}>\mathrm{S})] \mathrm{E}[\mathrm{R} \mid \mathrm{R}>\mathrm{S}]-\mathrm{D}\left(1+\mathrm{i}_{0}\right)
$$

As will be shown, however, this first-best value cannot be obtained under either regime.

\section{No Violations of Absolute Priority}

Let us start with the regime in which Ch. 11 is not available and value is distributed according to AP. We will analyze the outcome under this regime in three steps: (1) Given any agreement between the parties on the value of $i$, how would the equityholders decide at $t=1$ between the projects? (2) Given the expected management decision by equityholders, what i would be chosen ex ante at $\mathrm{t}=0$ ?, and (3) Given that particular i, what project would the equityholders choose, and what $\mathrm{V}_{0}$ would that choice imply?

\section{A. The Equityholders' Choice Given an Interest Rate}

First consider the choice of a project at $t=1$ under a regime without Ch. 11 and AP violations. Given i, once the equityholders observe R, they will choose the risky project if and only if:

$$
\mathrm{E}_{\theta} \max [\theta \mathrm{R}-\mathrm{D}(1+\mathrm{i}), 0] \geq \max [\mathrm{S}-\mathrm{D}(1+\mathrm{i}), 0]
$$

Let $R_{N}(i)$ denote the smallest nonnegative value of $R$ that makes the left- and right-hand sides of (2) equal. There always exists such a value. The equityholders will choose the risky project if and only if $\mathrm{R} \geq \mathrm{R}_{\mathrm{N}}(\mathrm{i})$.

Using Jensen's inequality and the convexity of the max function in (2), one can show that if a risky project with $R=S$ does not always lead to insolvency, that is, $\theta \mathrm{S}>\mathrm{D}(1+\mathrm{i})$, then the left- hand side of (2) is strictly greater than its right-hand side for $\mathrm{R}=\mathrm{S}$. Furthermore, if $\mathrm{D}(1+\mathrm{i}) \geq \mathrm{S}$, then the right-hand side of $(2)$ equals 0 , and $\mathrm{R}_{\mathrm{N}}(\mathrm{i})=0$. It follows that for any given

\footnotetext{
${ }^{8}$ See Bebchuk and Chang (1992) for an analysis of how Ch. 11 can enable equityholders to obtain more than their contractual right in situations of "near-insolvency."
} 
i:

$$
\mathrm{R}_{\mathrm{N}}(\mathrm{i})<\mathrm{S} \text {. }
$$

Inequality (3) implies that the equityholders may choose the risky project even if $\mathrm{R}<\mathrm{S}$. This result is the familiar moral hazard problem (see, e.g., Jensen and Meckling (1976)). The equityholders may choose the risky project inefficiently, because they have more to gain from a favorable outcome for this project than they have to lose from an unfavorable outcome.

\section{B. The Equilibrium Interest Rate}

Let $\mathrm{i}_{\mathrm{N}}$ be the interest rate set by the parties at $\mathrm{t}=0$ under the no-reorganization regime. Let $\mathrm{F}_{\mathrm{N}}(\mathrm{i})$ be the expected payment to debtholders for any given $\mathrm{i}$ under the regime with no $\mathrm{Ch}$. 11 and thus no AP violations. This expected payment must satisfy:

$$
\begin{aligned}
\mathrm{F}_{\mathrm{N}}(\mathrm{i})= & \operatorname{Pr}\left[\mathrm{R}<\mathrm{R}_{\mathrm{N}}(\mathrm{i})\right] \min [\mathrm{D}(1+\mathrm{i}), \mathrm{S}]+ \\
& \operatorname{Pr}\left[\mathrm{R} \geq \mathrm{R}_{\mathrm{N}}(\mathrm{i})\right] \mathrm{E}_{\mathrm{R}}\left\{\mathrm{E}_{\theta} \min [\mathrm{D}(1+\mathrm{i}), \theta \mathrm{R}] \mid \mathrm{R} \geq \mathrm{R}_{\mathrm{N}}(\mathrm{i})\right\} .
\end{aligned}
$$

Let us assume that there exists some $\mathrm{i}$ that satisfies the debtholders' constraint, $\mathrm{F}_{\mathrm{N}}(\mathrm{i}) \geq$ $\mathrm{D}\left(1+\mathrm{i}_{0}\right)$, and provides the equityholders with a positive expected value. ${ }^{9}$ In a competitive market for debt, the equilibrium interest rate $\mathrm{i}_{\mathrm{N}}$ will satisfy:

$$
\mathrm{F}_{\mathrm{N}}\left(\mathrm{i}_{\mathrm{N}}\right)=\mathrm{D}\left(1+\mathrm{i}_{0}\right)
$$

Note our assumption that there exists such an $i_{N}$ that leaves the equityholders with a positive expected value implies that this $i_{N}$ allows some positive probability of solvency. Thus, $i_{N}$

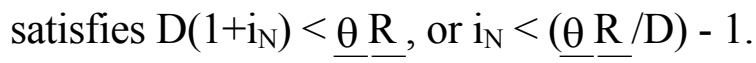

\footnotetext{
${ }^{9}$ If the moral hazard problem is sufficiently severe, such an i might not exist. In such a case, the moral hazard problem would prevent the firm from borrowing the amount D.
} 


\section{The Initial Value}

Let $\mathrm{V}_{0}^{\mathrm{N}}$ be the ex ante value of the equity under the no-reorganization regime. As (5) reveals, the debtholders in this case capture an expected return $\mathrm{i}_{0}$. Therefore:

$$
\mathrm{V}_{0}^{\mathrm{N}}=\operatorname{Pr}\left[\mathrm{R}<\mathrm{R}_{\mathrm{N}}\left(\mathrm{i}_{\mathrm{N}}\right)\right] \mathrm{S}+\operatorname{Pr}\left[\mathrm{R} \geq \mathrm{R}_{\mathrm{N}}\left(\mathrm{i}_{\mathrm{N}}\right)\right] \mathrm{E}\left[\mathrm{R} \mid \mathrm{R} \geq \mathrm{R}_{\mathrm{N}}\left(\mathrm{i}_{\mathrm{N}}\right)\right]-\mathrm{D}\left(1+\mathrm{i}_{0}\right)
$$

Note that since $\mathrm{R}_{\mathrm{N}}\left(\mathrm{i}_{\mathrm{N}}\right)<\mathrm{S}$ (see (3)), the $\mathrm{V}_{0}{ }^{\mathrm{N}}$ in (6) falls short of the first-best value $\mathrm{V}_{0}{ }^{*}$ in (1). Specifically, $\mathrm{V}_{0}{ }^{\mathrm{N}}$ is lower than $\mathrm{V}_{0}{ }^{*}$ by the difference: $\operatorname{Pr}\left[\mathrm{R}_{\mathrm{N}}\left(\mathrm{i}_{\mathrm{N}}\right) \leq \mathrm{R}<\mathrm{S}\right] \mathrm{E}\left[\mathrm{S}-\mathrm{R} \mid \mathrm{R}_{\mathrm{N}}\left(\mathrm{i}_{\mathrm{N}}\right) \leq \mathrm{R}\right.$ $<\mathrm{S}]$.

\section{Violations of Absolute Priority}

We now turn to analyze the reorganization regime in which $\mathrm{CH}$. 11 is available and deviations from AP occur. We will follow the same three steps as in the preceding analysis of the no-reorganization regime. Accordingly we start with the question of how the equityholders will choose between the projects given an interest rate.

\section{A. The Equityholders' Choice Given an Interest Rate}

Consider the choice of a project at $t=1$ under a regime with $\mathrm{Ch}$. 11 . Given $\mathrm{i}$, once the equityholders observe $\mathrm{R}$, they will choose the risky project if and only if:

$$
\mathrm{E}_{\theta} \max [\theta \mathrm{R}-\mathrm{D}(1+\mathrm{i}), \alpha \theta \mathrm{R}] \geq \max [\mathrm{S}-\mathrm{D}(1+\mathrm{i}), \alpha \mathrm{S}]
$$

Let $R_{R}(i)$ denote the unique value of $R$ that makes the left- and right-hand sides of (7) equal. There always exists such a value. The equityholders will choose the risky project if and only if $R \geq R_{R}(i)$.

We can now compare the project choices at $\mathrm{t}=1$ under the two regimes for any given $\mathrm{i}$. As the following proposition indicates, for any given $\mathrm{i} \leq[\mathrm{S}(1-\alpha) / \mathrm{D}]-1$, the availability of $\mathrm{Ch}$. 
11 makes the equityholders more likely to choose the risky project: ${ }^{10}$

Proposition 1: $\mathrm{R}_{\mathrm{R}}(\mathrm{i})<\mathrm{R}_{\mathrm{N}}(\mathrm{i})$, for any $\mathrm{i} \leq[\mathrm{S}(1-\alpha) / \mathrm{D}]-1$.

Remark: The intuition behind this result (which is proved in the Appendix) is as follows. Under both regimes, the equityholders have an inefficient incentive to invest in risky projects. The availability of Ch. 11, however, increases this incentive (holding fixed the interest rate) because it increases the attractiveness of a risky project for the equityholders. Under both regimes, the equityholders capture the benefits of a favorable outcome from the risky project, whereas the debtholders bear part of the costs of an unfavorable outcome. With Ch. 11, however, the debtholders bear a larger fraction (and the equityholders bear a smaller fraction) of the downside risk, which makes the risky project more attractive for the equityholders (relative to the situation without Ch. 11). Thus, the presence of Ch. 11 enhances the severity of the moral hazard problem.

\section{B. The Equilibrium Interest Rate}

Let $i_{R}$ be the interest rates set by the parties at $t=0$ under the reorganization regime. Let $F_{R}(i)$ be the expected payment to debtholders for any given i under the reorganization regime. This payment must satisfy:

$$
\begin{aligned}
F_{R}(i)= & \operatorname{Pr}\left[R<R_{R}(i)\right] \min [D(1+i), S(1-\alpha)]+ \\
& \operatorname{Pr}\left[R \geq R_{R}(i)\right] E_{R}\left\{E_{\theta} \min [D(1+i), \theta R(1-\alpha)] \mid R \geq R_{R}(i)\right\} .
\end{aligned}
$$

Let us assume that there exists some i that satisfies the debtholders' individual rationality constraint, $\mathrm{F}_{\mathrm{R}}(\mathrm{i}) \geq \mathrm{D}\left(1+\mathrm{i}_{0}\right) .{ }^{11}$ In the competitive debt market, $\mathrm{i}_{\mathrm{R}}$ will satisfy:

\footnotetext{
${ }^{10}$ Under this condition concerning i, only the risky project, but not the safe project, may lead to corporate reorganization.

${ }^{11}$ Again, if the moral hazard problem is sufficiently severe, such an i might not exist, in which case the moral hazard problem would prevent the firm from borrowing the amount $\mathrm{D}$.
} 


$$
\mathrm{F}_{\mathrm{R}}\left(\mathrm{i}_{\mathrm{R}}\right)=\mathrm{D}\left(1+\mathrm{i}_{0}\right)
$$

Let us also assume that $\mathrm{S}(1-\alpha) / \mathrm{D}$ is large enough to ensure that the debtholders' constraint can be satisfied by some $i \leq[S(1-\alpha) / D]-1$, so that $i_{R} \leq[S(1-\alpha) / D]-1$. This assumption implies that $i_{R}$ is small enough to ensure that the safe project will not lead to Ch. 11 (only a risky project will).

Proposition 2: The equilibrium interest rate is higher under the reorganization regime with AP violations than under the no-reorganization regime: $i_{R}>i_{N}$.

Remark: The proof of the proposition is in the Appendix, but its intuition might be briefly described as follows. Introducing violations of AP while maintaining the interest rate $\mathrm{i}_{\mathrm{N}}$ would hurt the debtholders for two reasons. First, the equityholders would be more inclined to choose a risky project (Proposition 1). Second, the debtholders would expect to get a smaller fraction of the final output in the event of insolvency or financial distress. For both reasons, introducing AP violations while keeping $i_{N}$ would give the debtholders less than competitive returns. Therefore, a higher interest rate than $i_{N}$ will be necessary to offer the debtholders the same competitive expected return $\mathrm{D}\left(1+\mathrm{i}_{0}\right)$.

\section{The Initial Value}

Let us now consider the initial equity value under the reorganization regime and compare it to the value under the no-reorganization regime. Let $\mathrm{V}_{0}{ }^{\mathrm{R}}$ denote the ex ante value of the equity under the reorganization regime. As (9) reveals, the debtholders capture an expected return $\mathrm{i}_{0}$, and thus:

$$
\mathrm{V}_{0}^{\mathrm{R}}=\operatorname{Pr}\left[\mathrm{R}<\mathrm{R}_{\mathrm{R}}\left(\mathrm{i}_{\mathrm{R}}\right)\right] \mathrm{S}+\operatorname{Pr}\left[\mathrm{R} \geq \mathrm{R}_{\mathrm{R}}\left(\mathrm{i}_{\mathrm{R}}\right)\right] \mathrm{E}\left[\mathrm{R} \mid \mathrm{R} \geq \mathrm{R}_{\mathrm{R}}\left(\mathrm{i}_{\mathrm{R}}\right)\right]-\mathrm{D}\left(1+\mathrm{i}_{0}\right)
$$

Note that since $\mathrm{R}_{\mathrm{R}}\left(\mathrm{i}_{\mathrm{R}}\right)<\mathrm{S}$ (see (8)), $\mathrm{V}_{0}{ }^{\mathrm{R}}$ in (10) falls short of the first-best value $\mathrm{V}_{0}{ }^{*}$ in (1) by the difference: $\operatorname{Pr}\left[\mathrm{R}_{\mathrm{R}}\left(\mathrm{i}_{\mathrm{R}}\right) \leq \mathrm{R} \leq \mathrm{S}\right] \mathrm{E}\left[\mathrm{S}-\mathrm{R} \mid \mathrm{R}_{\mathrm{R}}\left(\mathrm{i}_{\mathrm{R}}\right) \leq \mathrm{R} \leq \mathrm{S}\right]$. 
The initial value again depends upon the expected investment decisions given the equilibrium interest rate. Thus, to compare $\mathrm{V}_{0}{ }^{\mathrm{R}}$ and $\mathrm{V}_{0}{ }^{\mathrm{N}}$, we must begin with a comparison of $\mathrm{R}_{\mathrm{R}}\left(\mathrm{i}_{\mathrm{R}}\right)$ and $\mathrm{R}_{\mathrm{N}}\left(\mathrm{i}_{\mathrm{N}}\right)$.

Proposition 3: The likelihood that a risky project will be chosen is greater under the reorganization regime than under the no-reorganization regime: $\mathrm{R}_{\mathrm{R}}\left(\mathrm{i}_{\mathrm{R}}\right)<\mathrm{R}_{\mathrm{N}}\left(\mathrm{i}_{\mathrm{N}}\right)$.

Remark: This result, which is proved in the Appendix, can be intuitively explained as follows. The availability of Ch. 11 aggravates the moral hazard problem for two reasons. First, with Ch. 11, equityholders are more inclined to choose the risky project, because Ch. 11 shifts more downside risk from the equityholders to the debtholders. Second, the equilibrium interest rate is higher under the reorganization regime - and this further reduces the attractiveness of the safe project compared to the risky project.

Our result, that the moral hazard problem is more severe if Ch. 11 is available, leads us, by straightforward algebra, to the following conclusion.

Proposition 4: The initial equity value is lower under the reorganization regime than under the no-reorganization regime by the difference:

$$
\operatorname{Pr}\left[\mathrm{R}_{\mathrm{R}}\left(\mathrm{i}_{\mathrm{R}}\right) \leq \mathrm{R}<\mathrm{R}_{\mathrm{N}}\left(\mathrm{i}_{\mathrm{N}}\right)\right] \mathrm{E}\left[\mathrm{S}-\mathrm{R} \mid \mathrm{R}_{\mathrm{R}}\left(\mathrm{i}_{\mathrm{R}}\right) \leq \mathrm{R}<\mathrm{R}_{\mathrm{N}}\left(\mathrm{i}_{\mathrm{N}}\right)\right] .
$$

The equityholders bear the cost of any inefficient behavior, because the debtholders take the ex post opportunism of equityholders into account ex ante. More inefficient project choices are expected under the reorganization regime (Proposition 3). Therefore, $V_{0}{ }^{R}$ is lower than $V_{0}{ }^{N}$ by the cost of the additional inefficient project choices. 


\section{Note on Magnitude}

The magnitude of the efficiency costs of the AP violations - the extra moral hazard costs that such violations produce - is given by (11) above. And future research might wish to examine, both theoretically and empirically, the magnitude of these extra costs.

As emphasized earlier, the identified distortion exacerbates the moral hazard problem that would arise even without AP violations from the mere presence of limited liability. Even without AP violations, the presence of limited liability implies that the adoption of a risky project would impose a negative externality on existing debt, or, in other words, would force the debt to provide a "subsidy" to the equity. The introduction of AP violations provides extra "subsidy." Since debtholders commonly lose a substantial amount in bankruptcy even in the absence of AP violations, and AP violations are commonly limited to only a fraction of the bankruptcy value, it might be suggested that the extra subsidy might not be large relative to the basic subsidy arising from the mere presence of limited liability. ${ }^{12}$

Note, however, that the relative increase in the size of moral hazard costs produced by AP violations might be larger than the relative increase in the subsidy produced by them. The reason for this is that the marginal inefficient risky projects that would be induced if AP violations were added on top of limited liability are more inefficient than the inefficient risky projects that would be adopted under limited liability alone. That is, one should not equate the relative increase in moral hazard costs produced by AP deviations with the relative increase in the size of the subsidy produced by them. To estimate the relative increase in moral hazard costs, a more complex analysis would be needed, which would, among other things, have to

\footnotetext{
${ }^{12}$ I am grateful to an anonymous referee for raising this question. The referee motivated this skeptical question by estimating the relative increase in the size of the subsidy using some of the empirical evidence on the average recovery in bankruptcy and the average size of deviations from AP. Assuming that the average reorganization value is half of the value of the outstanding debt, and that the deviations from absolute priority average 10 percent of the reorganization value, the referee calculated that the deviations from AP would increase the average subsidy to equity by only 10 percent.
} 
estimate (or make an assumption about) the distribution of inefficient risky projects.

Furthermore, note that the same skeptical observation can also be made about the magnitude of the beneficial effects of AP violations identified by other ex ante models of the effects of such violations. As was emphasized, a main point of this paper is that, unlike what one might otherwise infer from the literature modeling the ex ante effects of AP violations, such violations are not unambiguously beneficial. In the other existing models, the beneficial effects of AP violations result from the fact that the subsidy to equity provides equityholders with incentives to take certain beneficial ex ante actions. To the extent that this subsidy is not large, questions also arise about the magnitude of the beneficial effects identified by these other models. Thus, while questions regarding the size of the subsidy under the existing AP violations might raise doubts concerning whether the ex ante effects of these violations are important, they do not resolve the question of whether these violations are overall positive or negative, and thus do not undermine this paper's main point, that these violations might overall be undesirable.

\section{Other Ex Ante Decisions}

\section{A. Project Choice after the Onset of Financial Distress}

Let us now reconcile the result obtained above with the results in other papers that deviations from AP can have a beneficial effect on management decisions once the firm is in financial distress. Observe that a critical assumption in the preceding analysis was that the safe project, the one that involves less output volatility, is associated with lower likelihood of insolvency. This assumption is likely to hold for most companies that are safely distant from financial distress. Once the fortunes of a firm deteriorate, however, it might reach a situation in which a safe investment policy would produce a greater likelihood of insolvency than would a riskier policy. In such situations, which are common in financial distress, Ch. 11 might well 
operate to reduce the moral hazard distortion in favor of risky projects.

Consider a situation in which the safe project's return is $\mathrm{S}<\mathrm{D}(1+\mathrm{i})$. In this case, if the safe project is chosen, the company will surely reach insolvency. Consequently, if Ch. 11 is not available, the distortion would be substantial - the equityholders have nothing to lose and something to gain from choosing a risky project; therefore, they will choose any risky project, whatever its expected return, as long as it offers some chance of solvency. In contrast, with $\mathrm{Ch}$. 11, the equityholders can expect to get something in the event of insolvency, and it is thus no longer the case that they have nothing to lose if they choose a risky project with a very low expected return. Consequently, they will now choose the risky project only if its expected return exceeds a certain threshold. Thus, consistent with the results of other papers (see Eberhart and Senbet (1993) and Gertner and Scharfstein (1991)), when the firm is already in financial distress, Ch. 11 would have the positive effect of reducing moral hazard.

\section{B. Decisions concerning Distributions and Borrowing}

The model suggests that Ch. 11 affects not only ex ante choices between safe and risky projects but also other ex ante management decisions. In addition to the "asset substitution" problem concerning project choice, the presence of debt also creates problems of "asset dilution" and "claim dilution" (Smith and Warner (1979)). The asset dilution problem concerns decisions about distributions to equityholders - the equityholders have an incentive to take an excessive value out of the firm (say, in the form of dividends or salaries). The claim dilution problem concerns decisions to take extra debt when some debt is already in place - the equityholders have an incentive to take an excessive amount of additional debt.

The presence of $\mathrm{Ch} .11 \mathrm{can}$ be shown to aggravate the problems of asset dilution and claim dilution for exactly the same reason that it aggravates the asset substitution problem. In the presence of debt, equityholders will tend to withdraw too many assets and take too much extra debt because, in the event of insolvency, some of the costs resulting from such actions 
would fall upon debtholders. The presence of Ch. 11 increases the fraction of the loss borne by the debtholders in the event of insolvency - and, as a result, it strengthens these inclinations and thereby exacerbates the problems of asset dilution and claim dilution.

\section{Conclusion}

Much research on bankruptcy procedures and reform has focused on designing procedures that would eliminate deviations from AP. Consistent with the view underlying this line of research, this paper has analyzed how deviations from AP have an adverse ex ante effect on management decisions. Such deviations exacerbate the problems of asset substitution, asset dilution, and claim dilution.

To be sure, to determine whether deviations from AP are overall undesirable, it would be necessary to compare the magnitude of their negative effect, which this paper analyzes, with the magnitude of the positive effects of such deviations analyzed in other papers. One casual observation that is consistent with the view that AP is overall desirable is that, in countries like the U.K. in which insolvency law does not produce significant deviations from AP, parties do not generally provide for such deviations in their contracts. Whether the total ex ante effect of such deviations is positive or negative is an important question for future work to pursue. 


\section{APPENDIX}

Proof of Proposition 1: For any i satisfying the condition of the proposition, the right-hand sides of (2) and (7) are equal (because choosing the safe project would never result in the equityholders' use of Ch. 11). Recall that $\theta$ can be arbitrarily close to 0 with some positive probability, which implies:

$$
0<\operatorname{Pr}[\mathrm{D}(1+\mathrm{i})>\theta \mathrm{R}(1-\alpha)]=\operatorname{Pr}[\alpha \theta \mathrm{R}>\theta \mathrm{R}-\mathrm{D}(1+\mathrm{i})]
$$

Therefore, the left-hand side of (7) is strictly greater than the left-hand side of (2). Furthermore, if $\mathrm{R}=\mathrm{R}_{\mathrm{N}}(\mathrm{i})$, then the left-hand side of (2) is equal to the right-hand side of (2), which is equal to the right-hand side of (7). To make (7) an equality then, $\mathrm{R}$ must fall below that level: $\mathrm{R}_{\mathrm{R}}(\mathrm{i})<$ $R_{N}(i)$ Q.E.D.

Proof of Proposition 2: Recall that $i_{\mathrm{N}}$ will be the smallest value meeting the constraint that the debtholders are offered no less than a competitive return (which by (5) will be binding). Thus, any smaller i must fail to satisfy the relevant constraint:

$$
\mathrm{F}_{\mathrm{N}}(\mathrm{i})<\mathrm{F}_{\mathrm{N}}\left(\mathrm{i}_{\mathrm{N}}\right), \quad \forall \mathrm{i}<\mathrm{i}_{\mathrm{N}} .
$$

Therefore, if we suppose, contrary to the proposition, that $\mathrm{i}_{\mathrm{R}} \leq \mathrm{i}_{\mathrm{N}}$, then:

$$
\mathrm{F}_{\mathrm{N}}\left(\mathrm{i}_{\mathrm{R}}\right) \leq \mathrm{F}_{\mathrm{N}}\left(\mathrm{i}_{\mathrm{N}}\right)
$$

Furthermore, because $\mathrm{i}_{\mathrm{R}}$ satisfies $\mathrm{D}(1+\mathrm{i}) \leq \mathrm{S}(1-\alpha)$, a comparison of (4) and (8) reveals that:

$$
\mathrm{F}_{\mathrm{R}}\left(\mathrm{i}_{\mathrm{R}}\right)<\mathrm{F}_{\mathrm{N}}\left(\mathrm{i}_{\mathrm{R}}\right) .
$$

Together, (A3) and (A4) imply that $\mathrm{F}_{\mathrm{R}}\left(\mathrm{i}_{\mathrm{R}}\right)<\mathrm{F}_{\mathrm{N}}\left(\mathrm{i}_{\mathrm{N}}\right)$, which contradicts the implication of (5) and 
(9) that $\mathrm{F}_{\mathrm{R}}\left(\mathrm{i}_{\mathrm{R}}\right)=\mathrm{F}_{\mathrm{N}}\left(\mathrm{i}_{\mathrm{N}}\right)$.

Q.E.D.

Proof of Proposition 3: First, it will be useful to establish the following inequality:

$$
\mathrm{R}_{\mathrm{N}}{ }^{\prime}(\mathrm{i})<0, \quad \forall \mathrm{i}<(\mathrm{S} / \mathrm{D})-1 .
$$

Note that if $\mathrm{D}(1+\mathrm{i})<\mathrm{S}$, then the right-hand side of (2) is simply $\mathrm{S}-\mathrm{D}(1+\mathrm{i})$, and $\mathrm{R}_{\mathrm{N}}(\mathrm{i})$ is defined by the equality:

$$
\mathrm{E}_{\theta} \max \left[\theta \mathrm{R}_{\mathrm{N}}-\mathrm{D}(1+\mathrm{i}), 0\right]=\mathrm{S}-\mathrm{D}(1+\mathrm{i}),
$$

or equivalently:

$$
\mathrm{E}_{\theta} \max \left[\theta \mathrm{R}_{\mathrm{N}}, \mathrm{D}(1+\mathrm{i})\right]=\mathrm{S} .
$$

Note that $\theta \mathrm{R}_{\mathrm{N}}<\mathrm{D}(1+\mathrm{i})$ with some positive probability, because by assumption, $\theta$ can be arbitrarily close to 0 with some positive probability. Therefore, the left-hand side of (A6) is strictly increasing in $i$. Note also that $\theta \mathrm{R}_{\mathrm{N}}>\mathrm{D}(1+\mathrm{i})$ with some positive probability - otherwise, the equality in (A6) could not possibly hold, because $\mathrm{D}(1+\mathrm{i})<\mathrm{S}$ by assumption. Therefore, the left-hand side of (A6) is also strictly increasing in $\mathrm{R}_{\mathrm{N}}$. The right-hand side of (A6), however, is independent of both $i$ and $R_{N}$. Therefore, if $i$ increases, then to maintain the equality in (A6), $\mathrm{R}_{\mathrm{N}}$ must decrease, which proves (A5).

Given that $\mathrm{i}_{\mathrm{R}}$ is assumed to satisfy $\mathrm{D}(1+\mathrm{i}) \leq \mathrm{S}(1-\alpha)$, Proposition 1 implies that:

$$
\mathrm{R}_{\mathrm{R}}\left(\mathrm{i}_{\mathrm{R}}\right)<\mathrm{R}_{\mathrm{N}}\left(\mathrm{i}_{\mathrm{R}}\right) .
$$

Furthermore, Proposition 2 and (A5) together imply that:

$$
\mathrm{R}_{\mathrm{N}}\left(\mathrm{i}_{\mathrm{R}}\right)<\mathrm{R}_{\mathrm{N}}\left(\mathrm{i}_{\mathrm{N}}\right) .
$$

Together (A7) and (A8) yield Proposition 3.

Q.E.D. 


\section{REFERENCES}

Adler, Barry E., 1992, Bankruptcy and Risk Allocation," Cornell Law Review, 77, 439-489.

Aghion, Philippe, Oliver Hart, and John Moore, 1992, The economics of bankruptcy reform, Journal of Law, Economics and Organization 8, 523-546.

Baird, Douglas G., 1986, The uneasy case for corporate reorganizations, Journal of Legal Studies, 15, 127-147.

Baird, Douglas G., 1991, The initiation problem in bankruptcy, International Review of Law and Economics 11, 223-32.

Bebchuk, Lucian A., 1988, A new approach to corporate reorganizations, Harvard Law Review $101,775-804$.

Bebchuk, Lucian A. (1991), "The effects of chapter 11 and debt renegotiation on ex ante corporate decisions," Discussion Paper No. 104, Program in Law and Economics, Harvard Law School.

Bebchuk, Lucian A., 1998, Chapter 11, The New Palgrave Dictionary of Economics and the Law 1, 219-224.

Bebchuk, Lucian A., 1999, A generalization of the option scheme in bankruptcy, mimeo, Harvard University.

Bebchuk, Lucian A., 2000, Using options to divide value in corporate bankruptcy, European Economic Review 44, 829-843.

Bebchuk, Lucian A., and Howard Chang, 1992, Bargaining and the division of value in corporate reorganization, Journal of Law, Economics and Organization 8, 253-279.

Bebchuk, Lucian A. and Jesse Fried, 1996, "The uneasy case for the priority of secured claims in bankruptcy," Yale Law Journal, 105, 857-934.

Bebchuk, Lucian A. and Jesse Fried, 2001, "A new approach to valuing secured claims in bankruptcy," Harvard Law Review, 114, 2386-2436.

Bebchuk, Lucian A. and Randal Picker, 1993, "Bankruptcy rules, managerial entrenchment, and firm-specific human capital," Law \& Economics Working Paper No. 16, The University of Chicago Law School.

Berkovitch, Elazar, and Ronen Israel, 1998, The bankruptcy decision and debt contract 
renegotiations, European Finance Review 2, 1-27.

Berkovitch, Elazar, and Ronen Israel, 1999, Optimal bankruptcy law across different economic systems, The Review of Financial Studies 12, No.2, 347-377.

Berkovitch, Eli, Ronen Israel, and Jaime F. Zender, 1997, An optimal bankruptcy law and firmspecific investments, European Economic Review 41, 487-497.

Berkovitch, Eli, Ronen Israel, and Jaime F. Zender, 1998, The design of bankruptcy law: A case for management bias in bankruptcy reorganizations, Journal of Financial and Quantitative Analysis 33, 441-464.

Betker, Brian, 1995, Management's incentives, equity's bargaining power, and deviations from absolute priority in Chapter 11 bankruptcies, Journal of Business 68, 161-183.

Bhattacharyya, Sugato, and Rajdeep Singh, 1999, The resolution of bankruptcy by auction: Allocating the residual right of design, Journal of Financial Economics 54, 269-294.

Brown, David T., 1989, Claimholder incentive conflicts in reorganization: The role of bankruptcy law, Review of Financial Studies 2, 109-123.

Carapeto, Maria, 2000, Is bargaining in Chapter 11 costly? Working Paper, London City University Business School.

Cutler, David N., and Lawrence G. Summers, 1988, The costs of conflict resolution and financial distress: Evidence from the Texaco-Pennzoil litigation, Rand Journal of Economics 19, 157-172.

Eberhart, Allan C., William T. Moore, and Rodney L. Roenfeldt, 1990, Security pricing and deviations from the AP rule in bankruptcy proceedings, Journal of Finance 45, 14571469.

Eberhart, Allan C., and Lemma W. Senbet, 1993, Absolute priority rule violations and risk incentives for financially distressed firms, Financial Management, 101-114.

Franks, Julian R., Kjell Nybourg, and Walter N. Torous, 1996, A comparison of U.S., U.K., and German insolvency codes, Financial Management 25, 19-30.

Franks, Julian R., and Walter N. Torous, 1989, An empirical investigation of U.S. firms in reorganization, Journal of Finance 44, 747-769.

Franks, Julian R., and Walter N. Torous, 1994, A comparison of financial recontracting in distressed exchanges and Chapter 11 reorganizations, Journal of Financial Economics $35,349-370$. 
Gertner, Robert, and David Scharfstein, 1991, A theory of workouts and the effects of reorganization law, Journal of Finance 46, 1189-1222.

Giammarino, Ronald M., 1989, The resolution of financial distress, Review of Financial Studies 2, 25-47.

Gilson, Stuart C., Kose John, and Larry H. P. Lang, 1990, Troubled debt restructurings: An empirical study private reorganization of firms in default, Journal of Financial Economics 27, 315-353.

Green, Richard C., 1984, Investment incentives, debt, and warrant, Journal of Financial Economics 13, 115-136.

Hart, Oliver, 1995, Firms, Contracts, and Financial Structure, Clarendon Lectures in Economics, Oxford University Press, Oxford.

Heinkel, Robert, and Josef Zechner, 1993, Financial distress and optimal capital structure adjustments, Journal of Economics \& Management Strategy 2, No. 4, 531-565.

Jensen, Michael, 1991, Corporate control and the politics of finance, Journal of Applied Corporate Finance 4, 13-33.

Jensen, Michael C., and William H. Meckling, 1976, Theory of the firm: Managerial behavior, agency costs and ownership structure, Journal of Financial Economics 3, 305-360.

Lang, Larry, and Rene Stulz, 1992, Contagion and competitive intra-industry effects of bankruptcy announcements, Journal of Financial Economics, 45-60.

Povel, Paul (1996), “Optimal 'Soft' or 'Tough' Bankruptcy Procedures," Financial Markets Group Discussion Paper No. 240, London School of Economics.

Rhodes-Kropf, Matthew, and S. Viswanathan, 2000, Corporate reorganizations and non-cash auctions, Journal of Finance 55, 1807-1849.

Smith, Clifford W., Jr., and Jerold B. Warner, 1979, On financial contracting: An analysis of bond covenants, Journal of Financial Economics 7, 117-161.

Warner, Jerold B., 1977, Bankruptcy costs: Some evidence, Journal of Finance 32, 337-347.

Weiss, Lawrence A., 1990, Bankruptcy resolution: Direct costs and violation of priority of claims, Journal of Financial Economics 13, 137-151.

White, Michelle J., 1989, The corporate bankruptcy decision, Journal of Economic 
Perspectives 3, 129-151. 